Pacific Journal of Mathematics

A CHARACTERIZATION OF COMPLETELY REGULAR FIELDS 


\title{
A CHARACTERIZATION OF COMPLETELY REGULAR FIELDS
}

\author{
William Yslas VÉLEZ
}

Dedicated to H. B. Mann on the occasion of his Seventieth Birthday

\section{We prove a theorem on tamely ramified extensions and apply this theorem to obtain a characterization of completely regular fields.}

Let $Q_{p}$ denote the $p$-adic completion of $Q, F$ a finite extension of $Q_{p}, e\left(F \mid Q_{p}\right)=a$, the ramification degree of $F$ over $Q_{p}$, and $\zeta_{p}$ a primitive $p^{\text {th }}$ root of unity.

We say that $F$ is regular if $\zeta_{p} \notin F$.

When first studying the extension $F\left(\zeta_{p}\right)$ over $F$, it is a common error to assume that the extension $F\left(\zeta_{p}\right)$ over $F$ is ramified. Or, to put it another way, that if $K$ is an unramified extension of $F$, then $K$ must also be regular.

On this question, Borevič, [1], has made the following definition:

Let $K \supset F, e(K \mid F)=1$. If $\zeta_{p} \notin K$, for all such $K$, then we say that $F$ is completely regular.

Using class field theoretic techniques, Borevič, [1], has given a characterization of completely regular fields. This characterization is a corollary to the following theorem.

Theorem. Let $L \cap F=L^{\prime}$, where $e\left(L^{\prime} \mid Q_{p}\right)=l$, degree $\left(L \mid L^{\prime}\right)=$ $e\left(L \mid L^{\prime}\right)=f,(f, p)=1$ and $d=(a / l, f)$. Then $L=L^{\prime}\left(\pi^{1 / f}\right)$, where $\pi$ is some prime element in $L^{\prime}$ and $e\left(F\left(\pi^{1 / f}\right) \mid F\right)=f / d$. Furthermore, if $K$ is an unramified extension of $F$, then $e\left(K\left(\pi^{1 / f}\right) \mid K\right)=f / d$.

Proof. Given $(a / l, f)=d$, we find an $x$ such that $(x, f)=1$ and $(a / l) x-y f=d$. To find $x$, set $d=d_{1} d_{2}$, where $d_{2}$ is the largest divisor of $d$ such that $\left(f_{1}, d_{2}\right)=1$, where $f_{1}=f / d$. Then $\left(f_{1} d_{1}, d_{2}\right)=1$. Let $(a / l d) \cdot x_{1} \equiv 1\left(\bmod f_{1}\right)$. Since $\left(f_{1} d_{1}, d_{2}\right)=1$, we can solve the system of congruences $x \equiv x_{1}\left(\bmod f_{1} d_{1}\right), x \equiv 1\left(\bmod d_{2}\right)$.

Since $(f, p)=1$, we have that $L=L^{\prime}\left(\pi^{1 / f}\right)$ (Weiss, page 89 ), where $\pi$ is some prime element in $L^{\prime}$. Then $\pi=\alpha \pi_{1}^{a l l}$, where $\pi_{1}$ is some prime element in $F$ and $\alpha$ is a unit. Since $(f, x)=1$, we have that

$$
F\left(\pi^{1 / f}\right)=F\left(\left(\pi^{x}\right)^{1 / f}\right)=F\left(\left(\alpha^{x} \pi_{1}^{d}\right)^{1 / f}\right)=F\left(\left(\pi_{1}\left(\alpha^{x}\right)^{1 / d}\right)^{1 / f_{1}}\right) .
$$

But $F\left(\left(\alpha^{x}\right)^{1 / d}\right)$ is unramified over $F$ and $F\left(\pi^{1 / f}\right)$ over $F\left(\left(\alpha^{x}\right)^{1 / d}\right)$ is defined by the polynomial $x^{f_{1}}-\left(\alpha^{x}\right)^{1 / d} \pi_{1}$, which is an Eisenstein polynomial. 
Hence $e\left(F\left(\pi^{1 / f}\right) \mid F\right)=f / d$.

Let $e(K \mid F)=1$. Then $e\left(K\left(\pi^{1 / f}\right) \mid F\left(\pi^{1 / f}\right)\right)=1$. So we have that $e\left(K\left(\pi^{1 / f}\right) \mid F\right)=e\left(K\left(\pi^{1 / f}\right) \mid K\right) \cdot e(K \mid F)=e\left(K\left(\pi^{1 / f}\right) \mid K\right)$. But also $e\left(K\left(\pi^{1 / f}\right) \mid F\right)=$ $e\left(K\left(\pi^{1 / f}\right) \mid F\left(\pi^{1 / f}\right)\right) \cdot e\left(F\left(\pi^{1 / f}\right) \mid F\right)=e\left(F\left(\pi^{1 / f}\right) \mid F\right)$. Hence $e\left(K\left(\pi^{1 / f}\right) \mid F\right)=$ $e\left(K\left(\pi^{1 / f}\right) \mid K\right)=e\left(F\left(\pi^{1 / f}\right) \mid F^{\prime}\right)=f / d$.

COROLlary. The field $F$ is completely regular iff $p-1 \nmid e\left(F \mid Q_{p}\right)$.

Proof. Let degree $\left(F \cap Q_{p}\left(\zeta_{p}\right) \mid Q_{p}\right)=l<p-1$, with $f l=p-1$, and

$$
\text { degree }\left(Q_{p}\left(\zeta_{p}\right) \mid F \cap Q_{p}\left(\zeta_{p}\right)\right)=e\left(Q_{p}\left(\zeta_{p}\right) \mid F \cap Q_{p}\left(\zeta_{p}\right)\right)=f .
$$

Then $(f, p)=1$. Let $d=(a / l, f)$. Then $d=f$ iff $p-1 \mid a$. If $K$ is an unramified extension of $F$, then $e\left(K\left(\zeta_{p}\right) \mid K\right)>1$ iff $p-1 \nmid a$.

COROLlary. Let $K$ be an unramified extension of $F$ and $p-1 \mid a$, then $\zeta_{p} \in K$ iff $(p-1) / l \mid$ degree $(K \mid F)$, where $l=\operatorname{degree}\left(F \cap Q_{p}\left(\zeta_{p}\right) \mid Q_{p}\right)$.

Proof. If $p-1 \mid a$, then $d=f=(\alpha / l, f)$. So $e\left(F\left(\zeta_{p}\right) \mid F\right)=1$ and degree $\left(F\left(\zeta_{p}\right) \mid F\right)=(p-1) / l$.

If $\zeta_{p} \in K$, then $K \supset F\left(\zeta_{p}\right) \supset F$. But degree $\left(F\left(\zeta_{p}\right) \mid F\right)=(p-1) / l$, so $(p-1) / l \mid$ degree $(K / F)$.

Conversely, if $(p-1) / l \mid$ degree $(K \mid F)$, then since $K$ over $F$ has cyclic galois group, we have a field $F_{1}, K \supset F_{1} \supset F$, where degree $\left(F_{1} \mid F\right)=$ $(p-1) / l$ and $e\left(F_{1} \mid F\right)=1$. But we have shown that $e\left(F\left(\zeta_{p}\right) \mid F\right)=1$, and degree $\left(F\left(\zeta_{p}\right) \mid F\right)=(p-1) / l$. Hence $F_{1}=F\left(\zeta_{p}\right)$, since there is exactly one unramified extension for each degree. So $\zeta_{p} \in K$.

\section{REFERENCES}

1. Z. I. Borevič, On regular local fields, Vestnik Leningrad. Univ., 17 (1962), No. 13, 142-145.

2. E. Weiss, Algebraic Number Theory, McGraw-Hill Book Company, Inc., New York, 1963.

Received February 3, 1976. The author was supported in part by a Fellowship from the Ford Foundation and by the U. S. Energy Research and Development Administration (ERDA). The author is presently at Sandia Laboratories.

UNIVERSITY OF ARIZONA

AND

SANDIA LABORATORIES

Albuquerque, NM 


\title{
PACIFIC JOURNAL OF MATHEMATICS
}

\author{
EDITORS
}

\author{
RICHARD ARENS (Managing Editor) \\ University of California \\ Los Angeles, California 90024
}

\author{
R. A. Beaumont \\ University of Washington \\ Seattle, Washington 98105
}

J. DugundjI

Department of Mathematics

University of Southern California

Los Angeles, California 90007

D. Gilbarg and J. Milgram

Stanford University

Stanford, California 94305

\section{ASSOCIATE EDITORS}
E. F. BECKENBACH
B. H. NEUMANN
F. WOLF
K. Yoshida

\section{SUPPORTING INSTITUTIONS}

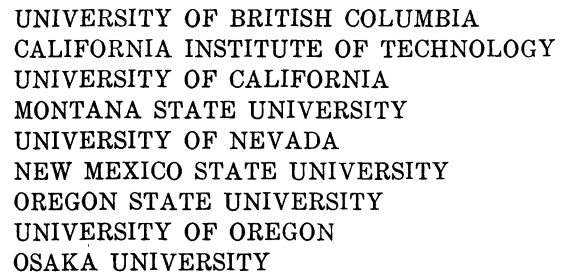

UNIVERSITY OF BRITISH COLUMBIA CALIFORNIA INSTITUTE OF TECHNOLOGY UNIVERSITY OF CALIFORNIA MONTANA STATE UNIVERSITY UNIVERSITY OF NEVADA NEW MEXICO STATE UNIVERSITY OREGON STATE UNIVERSITY UNIVERSITY OF OREGON OSAKA UNIVERSITY

\author{
UNIVERSITY OF SOUTHERN CALIFORNIA \\ STANFORD UNIVERSITY \\ UNIVERSITY OF HAWAII \\ UNIVERSITY OF TOKYO \\ UNIVERSITY OF UTAH \\ WASHINGTON STATE UNIVERSITY \\ UNIVERSITY OF WASHINGTON

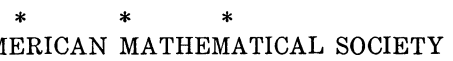

The Supporting Institutions listed above contribute to the cost of publication of this Journal, but they are not owners or publishers and have no responsibility for its content or policies.

Mathematical papers intended for publication in the Pacific Journal of Mathematics should be in typed form or offset-reproduced, (not dittoed), double spaced with large margins. Please do not use built up fractions in the text of your manuscript. You may however, use them in the displayed equations. Underline Greek letters in red, German in green, and script in blue. The first paragraph or two must be capable of being used separately as a synopsis of the entire paper. Items of the bibliography should not be cited there unless absolutely necessary, in which case they must be identified by author and Journal, rather than by item number. Manuscripts, in triplicate, may be sent to any one of the editors. Please classify according to the scheme of Math. Reviews, Index to Vol. 39. All other communications should be addressed to the managing editor, or Elaine Barth, University of California, Los Angeles, California, 90024.

The Pacific Journal of Mathematics expects the author's institution to pay page charges, and reserves the right to delay publication for nonpayment of charges in case of financial emergency.

100 reprints are provided free for each article, only if page charges have been substantially paid. Additional copies may be obtained at cost in multiples of 50 .

The Pacific Journal of Mathematics is issued monthly as of January 1966. Regular subscription rate: $\$ 72.00$ a year (6 Vols., 12 issues). Special rate: $\$ 36.00$ a year to individual members of supporting institutions.

Subscriptions, orders for back numbers, and changes of address should be sent to Pacific Journal of Mathematics, 103 Highland Boulevard, Berkeley, California, 94708.

PUBLISHED BY PACIFIC JOURNAL OF MATHEMATICS, A NON-PROFIT CORPORATION

Printed at Kokusai Bunken Insatsusha (International Academic Printing Co., Ltd.), 8-8, 3-chome, Takadanobaba, Shinjuku-ku, Tokyo 160, Japan.

Copyright (C) 1975 by Pacific Journal of Mathematics Manufactured and first issued in Japan 


\section{Pacific Journal of Mathematics}

\section{Vol. 63, No. 2 \\ April, 1976}

Joseph Anthony Ball and Arthur R. Lubin, On a class of contractive perturbations

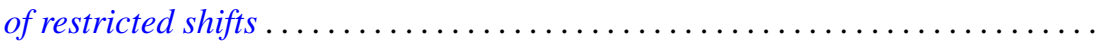

Joseph Becker and William C. Brown, On extending higher derivations generated

by cup products to the integral closure .......................

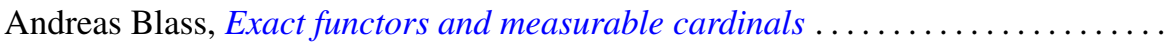

Joseph Eugene Collison, A variance property for arithmetic functions . . . . . . . . . .

Craig McCormack Cordes, Quadratic forms over nonformally real fields with a

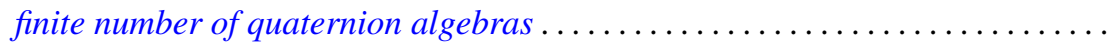

Freddy Delbaen, Weakly compact sets in $H^{1} \ldots \ldots \ldots \ldots \ldots \ldots \ldots \ldots \ldots$

G. D. Dikshit, Absolute Nörlund summability factors for Fourier series ..........

Edward Richard Fadell, Nielsen numbers as a homotopy type invariant. . ........

Josip Globevnik, Analytic extensions of vector-valued functions . . . . . . . . . . . .

Robert Gold, Genera in normal extensions . . . . . . . . . . . . . . . . . . . 389

Solomon Wolf Golomb, Formulas for the next prime

Robert L. Griess, Jr., The splitting of extensions of $S L(3,3)$ by the vector space

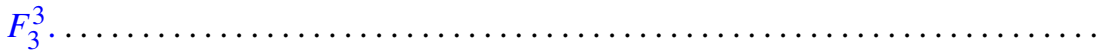

Thomas Alan Keagy, Matrix transformations and absolute summability .........

Kazuo Kishi, Analytic maps of the open unit disk onto a Gleason part.

Kwangil Koh, Jiang Luh and Mohan S. Putcha, On the associativity and commutativity of algebras over commutative rings . ..... . .

James C. Lillo, Asymptotic behavior of solutions of retarded differential difference equations.

John Alan MacBain, Local and global bifurcation from normal eigenvalues ..

Anna Maria Mantero, Sets of uniqueness and multiplicity for $L^{p}$

J. F. McClendon, Embedding metric families

L. Robbiano and Giuseppe Valla, Primary powers of a prime ideal .

Wolfgang Ruess, Generalized inductive limit topologies and barrelledness

properties.

Judith D. Sally, Bounds for numbers of generators of Cohen-Macaulay ideals

Helga Schirmer, Mappings of polyhedra with prescribed fixed points and fixed point indices.

Cho Wei Sit, Quotients of complete multipartite graphs

S. Sznajder and Zbigniew Zielezny, Solvability of convolution equations in $\mathscr{K}_{p}^{\prime}$,

$p>1$.

Mitchell Herbert Taibleson, The existence of natural field structures for finite

dimensional vector spaces over local fields

William Yslas Vélez, A characterization of completely regular fields

P. S. Venkatesan, On right unipotent semigroups ..............

Kenneth S. Williams, A rational octic reciprocity law ............

Robert Ross Wilson, Lattice orderings on the real field .......... 